\section{PŘEDSTAVENÍ NÁRODNÍHO ZDRAVOTNICKÉHO INFORMAČNÍHO PORTÁLU}

\section{Martin Komenda, Matěj Karolyi}

\section{Anotace}

Národní zdravotnický informační portál (NZIP) představuje systematickou cestu Ministerstva zdravotnictví ČR ke zlepšení komunikace a důvěryhodnosti prezentovaných informací směrem k veřejnosti. Publikací pouze plně prověřeného, garantovaného a metodicky standardizovaného obsahu se NZIP stane stěžejním komunikačním kanálem, který zprostředkuje potřebné informace $z$ oblasti zdravotní péče, prevence a podpory zdraví nejen pro státní správu, ale zejména pro širokou laickou i odbornou veřejnost. $V$ př́mé návaznosti na národní strategický rámec Zdraví 2030, který mimo jiné směřuje k zajištění systematické informovanosti v oblasti ochrany zdraví a zdravého životního stylu včetně posílení zdravotní gramotnosti, NZIP prezentuje původní autorský obsah provázaný na existující ověřené online zdroje např́íc odbornými portály z oblasti českého zdravotnictví. Primární ambicí projektu NZIP je zamezit roztříštěnosti informací a zajistit správnou interpretaci garantovaných materiálů prostřednictvím jednotné komunikační platformy. Ta bude určena především pro propagaci a využívání služeb ve zdravotnictví v souladu se strategickou podporou zdraví, a strategickými záměry resortu. NZIP přináší zvýšení důvěry laické i odborné veřejnosti k zdravotnickým informacím, zvýší zdravotní gramotnost populace a plošně zjednoduší přistup k dostupným online zdrojům, čímž mimo jiné přispěje $k$ propagaci zdravého životního stylu a preventivních programů garantovaných státem. Konferenční př́spěvek představí aktuální stav portálu nzip.cz společně s metodickým a technickým pozadím, které tvoří základní schéma spolupráce odborných garantů, autorského kolektivu, interních i externích recenzentů, vývojového týmu a Vědecké a rídící rady NZIP.

\section{Klíčová slova}

webový portál, zdravotnictví, dostupnost informací

\section{1 Úvod}

Současný stav prezentace zdravotnických informací v ČR na internetu je neuspokojivý a charakterizuje ho velká roztříštěnost a nízká míra důvěryhodnosti informací. Existuji desítky oborových portálů, částečně publikovaných státem, částečně takových, kde u prezentovaných informací nejsou uvedeni autoři, garanti, ani relevantní odkaz na zdroj [1]. Stát a jeho řízené organizace přitom disponují mimořádnou škálou odborných i statistických informací, které by mohly a měly být jednoduše dostupné na národním portálovém řešení, obdobně jako v jiných vyspělých státech. Národní zdravotnický informační portál (NZIP) umožní agregovat a zveřejňovat informace v oblasti zdravotnictví $v$ plně autorizované podobě a srozumitelně pro cílové skupiny. Celý projekt si klade za cíl zlepšit komunikaci a důvěryhodnost informací resortu zdravotnictví, a to jak mezi zástupci veřejné správy zajišťující zdravotní péči, tak směrem k občanům. Portál nzip.cz má ambici stát se stěžejním online kanálem, který zprostředkuje potřebné informace z oblasti zdravotní péče, prevence a podpory zdraví nejen pro státní správu, ale zejména pro širokou laickou i odbornou veřejnost. Zajistí koncepční zlepšování dostupnosti informací o zdravotnictví pro jednotlivé cílové skupiny a plošně bude zvyšovat důvěryhodnost prezentovaných zpráv uvnitř veřejné správy. V př́mé návaznosti na národní strategický rámec Zdraví 2030, který mimo jiné směřuje $\mathrm{k}$ zajištění systematické informovanosti v oblasti ochrany zdraví a zdravého životního stylu a k po- sílení zdravotní gramotnosti, bude NZIP prezentovat původní autorský obsah provázaný na existující ověěené online zdroje naprííc odbornými portály z oblasti českého zdravotnictví.

\section{Analýza potřeb}

Klíčový aspekt před zahájením řešení projektu představovala analýza potřeb a specifikace zadání. Prvním krokem byla realizace plošného průzkumu ve spolupráci s agenturou STEM, který se zaměřil na očekávání veřejnosti od Národního zdravotnického informačního portálu. Celkem bylo v listopadu 2018 dotázáno 1034 respondentů napříč populací ČR starší 18 let. Výsledky prímo vztažené k tématu Národního zdravotnického informačního portálu mimo jiné prokazují, že:

- Respondentům bylo předloženo celkem 14 typů informací, které by mohl obsahovat zdravotnický web Ministerstva zdravotnictví a České lékařské společnosti. Zájem o jednotlivé typy informací projevilo $v$ různé míre 50 a více procent respondentů.

- O nabízené typy informací mají zájem primárně věkové skupiny 30-44 nebo 45-59 let. Křivky zájmu o jednotlivé typy informací jsou u jednotlivých skupin internetových uživatelů „několikrát denně“ a "několikrát týdně“ velmi podobné.

- První trojce s nejlepším skóre je přes dílčí rozdíly ve všech případech jasná - „možnosti objednání k vyšetření či zákrokům", „ordinační hodiny lékařů" a "seznamy specialistů v regionech“. Věková skupina 45-59 let více než ostatní skupiny akcentuje "hodnocení lékařu a nemocnic", skupina 30-44 let "kompletní dokumentaci pacienta“. Každodenní uživatelé internetu více preferují právě „komunikaci s lékarem prostřednictvím internetu“.

- Při výběru tří typů informací, které na webu nesmějí chybět, jsou na prvním místě suverénně "ordinační hodiny lékařư " a na druhém "možnosti objednání k vyšetření či zákroku“. O třetí se dělí „seznamy specialistů v regionech" a "hodnocení lékařủ a nemocnic".

- Při stanovování pořadí důležitosti čtyř vybraných vlastností zdravotnického webu veřejnost vybrala jako nejdůležitější vlastnost portálu „diskrétnost a záruky bezpečnosti a důvěrnosti pro uživatele". Přes $50 \%$ prvního nebo druhého pořadí pak ještě získala "garance pravdivosti a ověřitelnosti publikovaných informací".

- Diskrétnost, záruky bezpečnosti jsou nejdůležitější hlavně pro respondenty s VŠ vzděláním, podobně je tomu i v prípadě garance pravdivosti a ověřitelnosti informací.

- Denní uživatelé internetu jako nejdůležitější vlastnost vedle diskrétnosti a bezpečnosti častěji preferují aktuálnost informací, méně častí uživatelé přehlednost a snadnou orientaci v portálu pro uživatele.

Dále byl v lednu 2019 realizován průzkum možné spolupráce s odbornými společnostmi a spolky ČLS JEP, kde byl hlavní cíl zmapovat oblast komunikace $s$ veřejností. Zpětnou vazbu zaslalo 44 zástupců odborných společností a spolků. Kromě jiného uvedli, že:

- Komunikace s veřejností je primárně realizována prostřednictvím webových stránek $(97,7 \%)$ a sociálními sítěmi $(83,7 \%)$.

- Informační servis je provozován e-mailem (75 \%) a telefonicky $(30,6 \%)$.

- Byla specifikována témata, která respondenti považují za svou odbornost za klíčová a aktuální z hlediska laické veřejnosti (např. informace podložené spolehlivými důkazy, očkování, základní péče o dítě, výživa a pohyb, psychosomatická onemocnění, zdravotní gramotnost, determinanty zdraví, zásady první pomoci a neodkladné resuscitace atd.)

Na základě získaných informací z výše uvedených šetření byla připravena projektová specifikace NZIP společně se zadáním. 


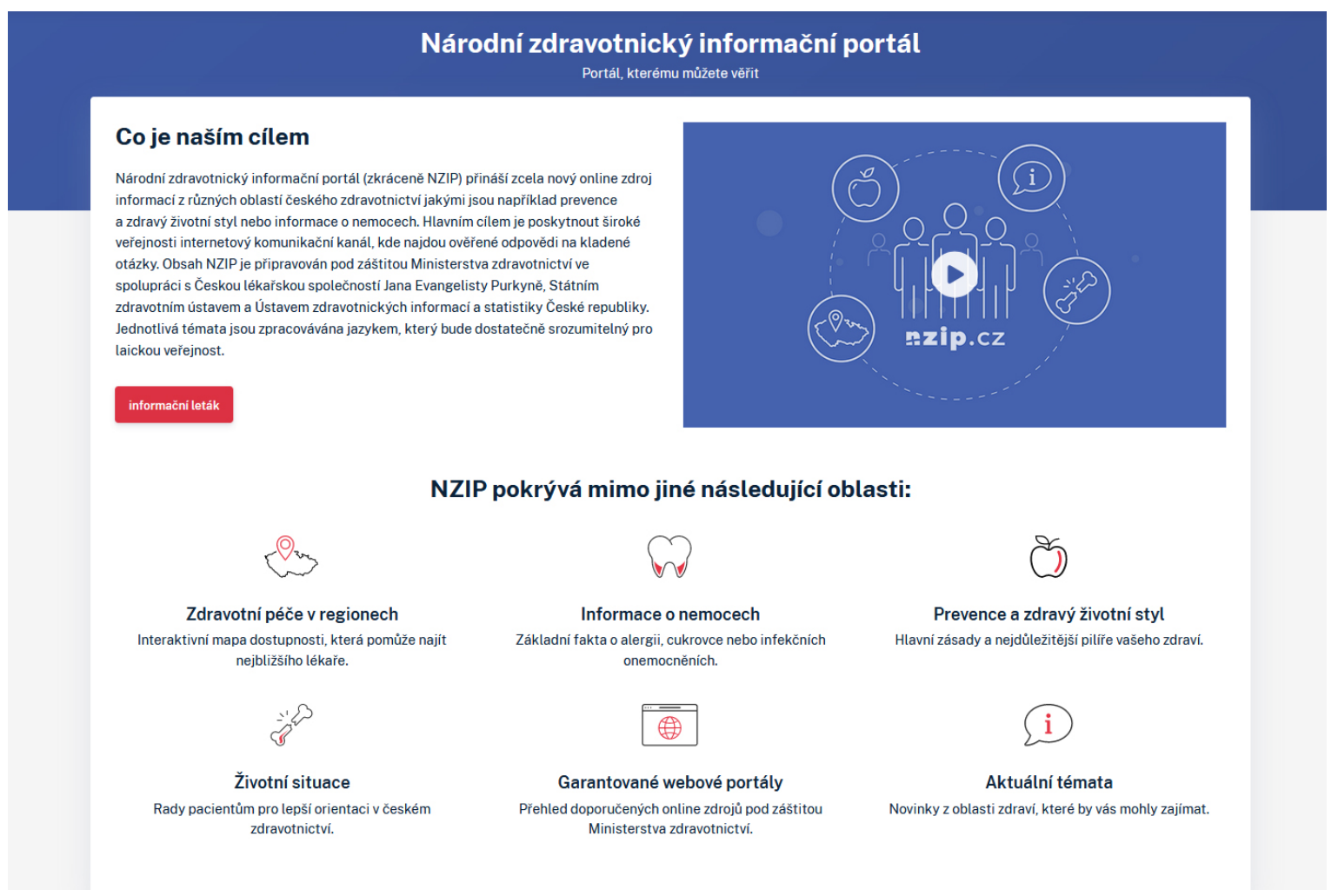

Obrázek 1 - Úvodní stránka NZIP (https://www.nzip.cz/)

\section{Návrh a vývoj NZIP}

Projekt je z pohledu systematického vývoje rozdělen do tří na sobě závislých etap, přičemž etapa I. cílí na vybudování pilotní verze robustního webového portálu tak, aby umožňoval uživatelsky přivětivou a efektivní publikaci garantovaného obsahu na internetu. Po metodické stránce je nedílnou součástí sestavení nového řídícího tělesa, které bude koncepčně rídit proces zveřejňování relevantních informací a určovat publikační plán na jednotlivá období. V rámci etapy II. následuje postupná a dlouhodobě udržitelná integrace původních článků a externích datových zdrojů, které přispějí ke komplexnímu pohledu na agendu zdravotnictví v České republice. Poslední etapa umožní rozšírit funkcionality portálu o vylepšené vlastnosti jako jsou např́klad edukační modul a pokročilé interaktivní a geografické vizualizace dostupných datových zdrojů.

\subsection{Technické zázemí a řešitelský tým}

Veškeré personální kapacity a technické nároky, které budou potřebné pro návrh, vývoj, testování a implementaci technického řešení, jsou zajištovány ÚZIS ČR. Základem je vývojový tým složený ze systémových analytiků, grafiků, webových designérů, databázových specialistů, vývojárư̊ webových aplikací, testerů a redaktorů. Koordinace a management celého projektu je podmíněn sestavením Vědecké a řídící rady NZIP, která zastřešuje a po odborné stránce garantuje obsah zveřejňovaný na portálu nzip.cz. Rada je složena ze zástupců MZ ČR (vedení resortu a zástupce Odboru komunikace $s$ veřejností), vedení České lékařské společnosti Jana Evangelisty Purkyně, Státního zdravotního ústavu a ÚZIS ČR. Samotná příprava a následná publikace příspěvků na portálu je v režii odborných redaktorů a editorů (zajistí technický převod dodaného obsahu do online podoby a nastaví potřebné atributy pro zveřejnění), kteří přímo podléhají zmíněné radě.

\subsection{Cílové skupiny}

Vybudování nového portálu bude mít výrazný prrínos přede- vším pro laickou veřejnost, pro kterou se NZIP stane zdrojem validních informací o zdraví a zdravotnictví. Důležitou rolí NZIP je šance zvýšit informační gramotnost, která potenciálním pacientům a jejich blízkým umožní činit kvalifikovaná a relevantní rozhodnutí směrem k péči o své vlastní zdraví. Další cílovou skupinou jsou státní př́spěvkové organizace a jejich zaměstnanci, kteři budu moci v souladu se stanoveným publikačním procesem zveřejňovat přispěvky veřejností poptávané. Zároveň jednotný formát sdělení zapadající do celkové komplexní struktury NZIP poskytne i samotným organizacím identifikovat nedostatečné pokryté a případně překrývající se oblasti, kterým je třeba dále se věnovat. Jednotný formát sdělení bude mít př́mý důsledek na pracovníky státních příspěvkových organizací snížením jejich administrativní zátěže a zefektivněním publikační činnosti. $V$ neposlední řadě se jedná o podporu organizačních složek státu včetně justice, obcí a krajủ, které díky NZIP získají kontrolovaný vstup informací pro kvalifikované rozhodování v oblasti zdravotních politik i dalších okruhů své činnosti ve zdravotnictví. Zásadním prínosem pro zaměstnance státních a akademických institucí společně s odbornými společnostmi je možnost plně reflektovat po obsahové stránce aktuální potřeby MZ ČR a publikovat v rámci doporučeného nosného média nezbytné informace pro laickou veřejnost.

\section{Představení NZIP}

V současné chvíli je NZIP po technické stránce finalizován tak, aby splňoval všechna kritéria a požadavky kladená na moderní webový portál. Ve své pilotní verzi nabídne více než 30 tematických kategorií, které jsou zaměřeny na hlavní zásady při prevenci a zdravém životním stylu, základní fakta o onemocněních, rady pacientům $v$ různých životních situacích a aktuální novinky z oblasti zdraví. Nebude chybět ani přehled doporučených online zdrojů pod záštitou Ministerstva zdravotnictví a rejstřík s krátkými vysvětleními pojmů pro laickou veřejnost. Jeden ze stěžejních požadavků veřejnosti, dostupnost zdravotní péče, je implementován jako speciální interaktivní modul s mapou 


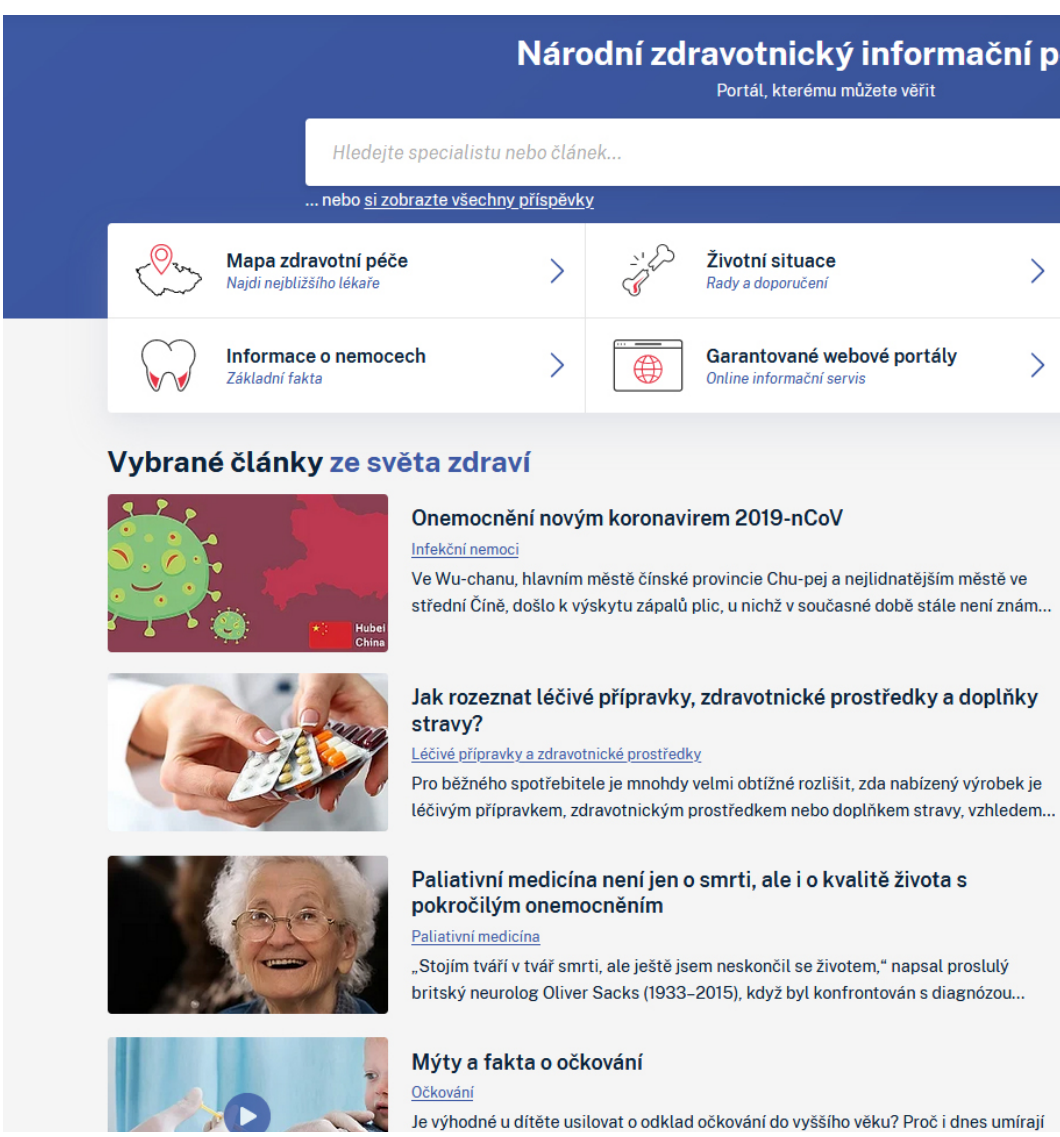

Obrázek 2 - Úvodní stránka po prihlášení s rozdělením na jednotlivé tematické celky

dostupnosti, která pomůže najít nejbližšího lékaře v závislosti na zadané adrese. Portál nzip.cz bude až do svého oficiálního spuštění dostupný pouze po přihlášení autorům, garantům a recenzentům obsahu. Pro veřejnost je bez omezení viditelná úvodní stránka, kde jsou uvedeny základní fakta o projektu NZIP společně s animovaným spotem.

\section{Závěrem}

Projekt NZIP zajistí nastavení důvěryhodné komunikace mezi občany - pacienty, zástupci veřejné správy a odbornými společnostmi. Veřejná správa bude prostřednictvím NZIP sdělovat laické veřejnosti potřebné informace $z$ českého zdravotnictví. Navíc bude mít veřejnost možnost prostřednictvím NZIP sdělovat, která témata nejsou dostatečně informačně pokryta, a to včetně hodnocení obsahu již publikovaného. Během celého projektu bude dobudována kompletní infrastruktura navázaná na dlouhodobý publikační plán. Metodické nastavení redakčních a publikačních procesů, které povede k publikaci pouze garantovaných informací a přejímání vhodného obsahu, je další přidanou hodnotou NZIP.

\section{Literatura}

[1.] Karolyi, Matěj, Komenda Martin., "Přehled elektronických informačních zdrojů ve zdravotnictví Č́" MEDSOFT 2019, od s. 40-49, 10 s, ISBN: 978-80-86742-46-5.

\section{Kontakt}

RNDr. Martin Komenda, Ph.D. Ústav zdravotnických informací a statistiky České republiky tel.: +420 725714940 e-mail: martin.komenda@uzis.cz web: $\underline{\text { https://uzis.cz/ }}$

Mgr. Matěj Karolyi

Ústav zdravotnických informací a statistiky České republiky e-mail:matej.karolyi@uzis.cz web: https://uzis.cz/ 